\title{
PELATIHAN PENINGKATAN KEMAMPUAN ARITMATIKA BAGI SISWA MTS. NW TANAK BEAK
}

\author{
Abdillah ${ }^{1}$ \\ 1Pendidikan Matematika, Universitas Muhammadiyah Mataram, ahmad_fawwaz18@yahoo.co.id
}

\begin{abstract}
ABSTRAK
Abstrak: Survey yang telah dilakukan dosen di Desa Tanak Beak, ternyata untuk anakanak usia sekolah baik tingkat sekolah dasar dan menengah di Desa Tanak Beak juga memiliki kemampuan aritmatika tergolong rendah. Meskipun sebagian besar dari mereka sudah mampu melakukan operasi-operasi matematika secara sederhana seperti penjumlahan, pembagian dan pengurangan bilangan akan tetapi proses yang dilakukan masih lambat. Mereka belum mengatahui cara-cara cepat dan jitu dalam berhitung, sedangkan di zaman sekarang ini apalagi untuk anak usia sekolah dalam menghadapi ujian atau semester di tuntut untuk melakukan pemecahan soal dengan cepat dan tepat termasuk dalam kemampuan berhitung atau aritmatika. Pelatihan yang dilakukan adalah menggunakan metode tutorial yang dilakukan oleh guru kepada siswa baik secara perorangan atau kelompok kecil siswa. Kegiatan pelatihan aritmatika di Desa Tanak Beak diikuti oleh siswa MTs. NW Tanak Beak yang memiliki kemampuan aritmatika rendah. Setelah melalui kegiatan pelatihan ini peserta telah mampu melakukan perhitungan-perhitungan bilangan baik puluhan, ratusan dan ribuan bahkan lebih dari itu. Peserta juga sudah mampu menggunakan sepuluh jari dan mampu menggunakan teknik-teknik berhitung sehingga mampu berhitung lebih cepat dari sebelumnya. Hanya saja pengetahuan peserta masih bersifat dasar dan perlu diadakan pelatihan yang lebih intensif lagi agar mereka dapat lebih terampil dalam berhitung.
\end{abstract}

Kata Kunci: Aritmatika, Operasi Matematika.

Abstract: Survey that has been done by lecturers in Tanak Beak Village, it turns out for school-age children both elementary and middle school level in Tanak Beak Village also has low arithmetic ability. Although most of them are able to perform simple mathematical operations such as addition, division and reduction of numbers but the process is still slow. They do not know how to fast and accurate in counting, while in this day and age especially for school-aged children in facing exam or semester in demand to do problem solving quickly and precisely included in arithmetic or arithmetic ability. The training is done using tutorial method done by teacher to student either individually or small group of students. Aritmatic training activities in Tanak Beak Village were followed by MTs students. NW Tanak Beak with low arithmetic capability. After going through this training, the participants have been able to do good count calculations tens, hundreds and thousands even more than that. Participants are also able to use ten fingers and able to use counting techniques so as to calculate faster than before. It's just that the participants' knowledge is still basic and needs to be held more intensive training again so that they can be more skilled in counting.

Keywords: Arithmetic, Mathematical Operation

Riwayat Artikel: Diterima: 16 Desember 2017, Disetujui: 15 Januari 2018 


\section{A. PENDAHULUAN}

Pendidikan merupakan upaya dasar untuk menyiapkan SDM melalui bimbingan, pengajaran, dan atau peranannya dimasa yang akan datang. Peran pendidikan dalam pembangunan masyarakat sangat penting dalam rangka upaya penyiapan sumber daya manusia yang berkualitas, mampu berkompetisi dalam tatanan kehidupan global serta menghadapi persaingan dimasa depan. Berkaitan dengan hal tersebut salah satu program perguruan tinggi Universitas Muhammadiyah Mataram adalah pengabdian masyarakat. Program ini merupakan persyaratan bagi mahasiswa menjelang akhir studi yang dilakukan dalam bentuk kuliah kerja nyata (KKN). Disamping mahasiswa, para dosen juga diwajibkan menerapkan Caturdarma Perguruan tinggi Universitas Muhammadiyah Mataram yaitu pendidikan dan pengajaran, penelitian, dan pengabdian masyarakat, serta Al Islam dan Kemuhammadiyahan. Berkaitan dengan hal di atas, pada kesempatan ini pengabdian masyarkat oleh dosen program studi Pendidikan Matematika FKIP dilaksanakan bersamaan dengan kegatan KKN mahasiswa.

Pengabdian masyarakat adalah suatu kegiatan yang bertujuan membantu masyarakat tertentu dalam beberapa aktivitas tanpa mengharapkan imbalan dalam bentuk apapun. Secara umum program ini dirancang oleh berbagai universitas atau institut yang ada di Indonesia untuk memberikan kontribusi nyata bagi bangsa Indonesia, khususnya dalam mengembangkan kesejahteraan dan kemajuan bangsa Indonesia. Bentuk-bentuk kegiatan Pengabdian Masyarakat dapat berupa bakti Sosial maupun mengajar.

Secara umum Tujuan Pengabdian Masyarakat di Perguruan Tinggi

1. Menciptakan inovasi teknologi untuk mendorong pembangunan ekonomi Indonesia dengan melakukan komersialisasi hasil penelitian;

2. Memberikan solusi berdasarkan kajian akademik atas kebutuhan, tantangan, atau persoalan yang dihadapi masyarakat, baik secara langsung maupun tidak langsung;

3. Melakukan kegiatan yang mampu mengentaskan masyarakat tersisih (preferential option for the poor) pada semua strata, yaitu masyarakat yang tersisih secara ekonomi, politik, sosial, dan budaya;

4. Melakukan alih teknologi, ilmu, dan seni kepada masyarakat untuk pengembangan martabat manusia dan kelestarian sumber daya alam.

Berdasarkan survey yang telah dilakukan dosen di Desa Tanak Beak, ternyata masih dihadapkan pada berbagai persoalan yang perlu diperhatikan khususnya dalam hal kemampuan berhitung. Mengingat sebagian besar warga masyarakat Desa Tanak Beak adalah berprofesi sebagai pedagang atau pengusaha jadi tidak terlepas dari berbagai kegiatan transaksi yang menuntut kemampuan berhitung, seperti menghitung persentase keuntungan atau kerugian, demikian halnya ketika melakukan jual beli terkadang sering salah dalam menjumlahkan harga-harga yang ditetapkan dan hal ini tentu akan menimbulkan kerugian kedua belah pihak. Meskipun di zaman modern ini telah ada alat-alat hitung modern seperti kalkulator dan lainnya, akan tetapi tidak semua masyarakat memilikinya. Selain masyarakat secara umum, ternyata untuk anak-anak usia sekolah baik tingkat sekolah dasar dan menengah di Desa Tanak Beak juga memiliki kemampuan aritmatika tergolong rendah. Meskipun sebagian besar dari mereka sudah mampu melakukan operasioperasi secara sederhana seperti penjumlahan, pembagian dan pengurangan bilangan akan tetapi proses yang dilakukan masih lambat. Mereka juga belum mampu menggunakan bantuan sepuluh jari tangan untuk melakukan perhitungan baik untuk tingkat puluhan, ratusan hingga ribuan. Mereka belum mengatahui caracara cepat dan jitu dalam berhitung, sedangkan di zaman sekarang ini apalagi untuk anak usia sekolah dalam menghadapi ujian atau semester di tuntut untuk 
melakukan pemecahan soal dengan cepat dan tepat termasuk dalam kemampuan berhitung atau aritmatika yang tidak hanya berguna dalam ilmu matematika saja, tetapi bisa ditemukan dalam berbagai disiplin ilmu, seperti ekonomi, fisika, kimia dan lainnya.

Dengan demikian berdasarkan permasalahan diatas maka perlu diadakan pelatihan peningkatan kemampuan aritmatika bagi masyarakat umum terutama anak-anak usia sekolah, yang mencakup pelatihan bagaimana melakukan perhitungan dengan cepat untuk operasi-operasi penjumlahan, perkalian, pembagian termasuk penerepan-penerapannya dalam berbagai disiplin ilmu baik ilmu sosia maupun ilmu alam, yang dalam hal ini pelatihan di lakukan bagi siswa MTs. NW Tanak Beak Kecamatan Batukeliang Utara, Kabupaten Lombok Tengah.

\section{B. METODE PELAKSANAAN}

Metode yang digunakan dalam kegiatan pelatihan ini adalah metode tutorial. Metode tutorial adalah suatu proses pengelolaan pembelajaran yang dilakukan melalui proses bimbingan yang diberikan/dilakukan oleh guru kepada siswa baik secara perorangan atau kelompok kecil siswa.

Metode ini juga sangat cocok diterapkan dalam model pembelajaran mandiri seperti pada pembelajaran jarak jauh di mana siswa terlebih dahulu diberi modul atau bahan ajar untuk dipelajari.

Dengan menerapkan metode tutorial ini, siswa diharapkan memperoleh pelayanan pembelajaran secara individual sehingga permasalahan spesifik yang dihadapinya dapat dilayani secara spesifik pula. Selain itu, siswa diharapkan dapat belajar dengan kecepatan yang sesuai dengan kemampuannya sendiri tanpa harus dipengaruhi oleh kecepatan belajar siswa yang lain.

\section{HASIL DAN PEMBAHASAN}

Pada tahap pelaksanaan kegiatan dibagi menjadi empat tahap, yaitu pelatihan aritmatika sederhana, menggunakan bantuan sepuluh jari menghitung operasi bilangan puluhan, ratusan dan ribuan, tips-tips menghitung cepat untuk perkalian dan pembagian, dan penerapan aritmatika dalam berbagai disiplin ilmu.

Pada pertemuan pertama peserta pelatihan diajarkan tentang aritmatika sederhana diantaranya tentang operasi penjumlahan, perkalian dan pembagian baik berupa bilangan bulat maupun pecahan. Materi ini sangat penting sekali sebab merupkan materi dasar yang sangat berperan tidak hanya dalam ilmu matematika sendiri tetapi dalam bidang lain baik dalam ilmu alam maupun sosial.

Pada pertemuan kedua dan ketiga materi yang diajarkan adalah bagaimana menggunakan bantuan sepuluh jari untuk melakukan perhitung operasi bilangan satuan seperti $8 \times 7$, puluhan seperti $29 \times 28$, ratusan seperti $325 \times 9$ dan ribuan. Hal ini sangat penting dilakukan agar peserta dilatih bagaimana memanfaatkan anggota tubuh terutama jari tangan untuk membantu melakukan perhitungan mengingat media-media atau alat hitung yang dimiliki sangat terbatas dan tidak selamanya media tersebut bisa di bawa. Oleh karenanya perlu di berikan pelatihan bagi anakanak usia sekolah Desa Ransing Bat untuk mampu mengoptimalkan anggota badan terutama sepuluh jari tangan dalam melakukan operasi bilangan puluhan, ratusan dan ribuan.

Pada pertemuan keempat dan kelima masing-masing materi yang diajarkan adalah Tips-tips menghitung cepat untuk perkalian dan pembagian. Pada tahap ini tidak jauh berbeda dengan tahap kedua hanya pada tahap ini dilakukan pelatihan memadukan keterampilan menggunakan jari tangan dan strategi dalam berhitung untuk bilangan-bilangan tertentu. Contoh untuk mencari nilai dari $75 \times 75$ adalah dengan mengalikan bilangan puluhan yaitu 7 dengan bilangan diatasnya yaitu 8 sehingga $7 \times 8=56$ dan untuk satuanya yaitu 5 dikuadratkan sehingga $5 \times 5=25$. 
Dengan demikian hasil yang diperoleh adalah gabungan dari 56 dan 25 yaitu 5625 . Dengan demikian $75 \times 75=5625$. Demikian juga untuk bilangan-bilangan lainnya baik puluhan, ratusan bahkan ribuan.

Pada pertemuan keenam materi yang diajarkan adalah bagaimana penerapan aritmatika dalam berbagai disiplin ilmu. Seperti dalam bidang ekonomi adalah bagaimana menghitung persentase untung rugi dalam dunia perdagangan, dalam fisika adalah bagaimana menentukan hubungan antara jarak, kecepatan dan waktu tempuh dalam suatu perjalanan dan lain sebagainya.

Secara umum, pelatihan peningkatan kemampuan aritmatika siswa MTs. NW di Desa Tanak Beak Kecamatan Batu Keliang Utara Kabupaten Lombok Tengah yang dilakukan selama enam kali pertemuan telah memberikan hasil yang baik untuk meningkatkan kualitas dan kemampuan siswa khususnya siswa MTs. NW Tanak Beak dalam berhitung. Hal ini terlihat diawal pertemuan siswa masih kesulitan dalam melakukan perhitungan, baik itu tekhnik berhitung, kecepatan maupun menerapkan sistem perhitungan dalam bentuk kontekstual. Setelah dilakukan pelatihan, dengan perlahan siswa mulai terlatih dan mulai mampu melakukan perhitungan dengan cepat dan tepat. Siswa juga mulai mampu menggunakan tekhnik sepuluh jari dalam melakukan perhitungan, baik itu perhitungan angaka puluhan, ratusan bahkan sampai ribuan.

Hasil dari kegiatan pelatihan ini juga diperoleh dari respon siswa dan guru selama kegiatan berlangsung. Para siswa merasa sangat senang dalam belajar karena diajarkan suatu metode yang baru dan mudah untuk di pahami dalam melakukan perhitungan-perhitungan, baik perhitungan sederhana sampai mengaplikasikan perhitungan yang ada kedalam bentuk kontekstual, seperti menghitung ketinggian suatu benda, menghitung kecepatan gerak sebuah benda, dan lainnya.

\section{SIMPULAN DAN SARAN}

Kegiatan pelatihan aritmatika di Desa Tanak Beak diikuti oleh anak-anak usia sekolah dan dewasa khsusnya yang memiliki kemampuan aritmatika rendah. Pemilihan peserta dilakukan dengan melibatkan pihak sekolah dan kepala dusun yang ada di wilayah Desa Tanak Beak. Setelah melalui kegiatan pelatihan ini peserta telah mampu melakukan perhitungan-perhitungan bilangan baik puluhan, ratusan dan ribuan bahkan lebih dari itu. Peserta juga sudah mampu menggunakan sepuluh jari dan mampu menggunakan teknik-teknik berhitung sehingga mampu berhitung lebih cepat dari sebelumnya. Hanya saja pengetahuan peserta masih bersifat dasar dan perlu diadakan pelatihan yang lebih intensif lagi agar mereka dapat lebih terampil dalam berhitung. Pelaksanaan kegiatan ini mendapat dukungan penuh dari warga masyarakat desa sehingga kegiatan ini dapat dilaksanakan sebanyak enam kali pertemuan.

Saran-saran yang pperlu diberika bagi masyarakat, khususnya masyarakat Desa Tanak Beak adalah

1. Mengadakan sanggar-sanggar pendidikan ataupun balai pelatihan yang melibatkan para pemuda maupun anak-anak usia sekolah

2. Mendorong anak-anak ataupun pemuda desa mengikuti kegiatan-kegiatan pelatihan yang ada di Desa Ransing Bat.

3. Turut menyediakan fasilitas ataupun sarana dan prasarana jika ada kegiatan pelatihan bagi warga desa.

Adapun saran yang perlu di berikan bagi Universitas Muhammadiyah Mataram adalah

1. Aktif dalam berkoordinasi dengan masyarakat desa khususnya Desa Tanak Beak dalam melaksanakan berbagai macam kegiatan yang dapat memajukan desa maupun Universitas Muhammadiyah Mataram. 
2. Aktif memberikan pelatihan bagi para dosen terutama dosen muda, sehingga mereka lebih dapat memberikan pengabdian secara maksimal yang dibutuhkan bagi masyarkat.

\section{UCAPAN TERIMA KASIH}

Tim penulis mengucapkan terima kasih kepada semua pihak yang telah memberikan dukungan terhadap kegiatan pengabdian ini, terutama kepada Dekan FKIP, Lembaga Pengabdian Pada Masyarakat (LPPM) Universitas Muhammadiyah Mataram, Kepala Sekolah MTs. NW dan Kepala Desa Tanak Beak serta seluruh masyarakat Desa Tanak Beak, sehingga kegiatan pengabdian ini dapat terlaksana dengan baik.

\section{DAFTAR RUJUKAN}

[1] Mulyono dan Abdurrahman, Pendidikan Bagi Anak Berkesulitan Belajar. Jakarta: PT Rineka Cipta, 1999.

[2] Slameto, Belajar Dan Faktor-faktor Yang Mempengaruhinya. Rineka Cipta: Jakarta, 2010.

[3] Soedjadi, Kiat Pendidikan di Indonesia. KonstatasiKeadaan Masa Kini Menuju Harapan Masa Depan. Jakarta: Depdiknas, 1999.

[4] LPM UM Mataram, Pedoman Pengabdian Kepada Masyarakat dan Prosedur Penulisan Proposal. UM. Mataram, 2017.

[5] Profil Desa Tanak Kec. Batu Keliang Utara, Kab. Lombok Tengah. Arsip Desa Tanak Beak, 2015.

\section{DOKUMENTASI KEGIATAN}

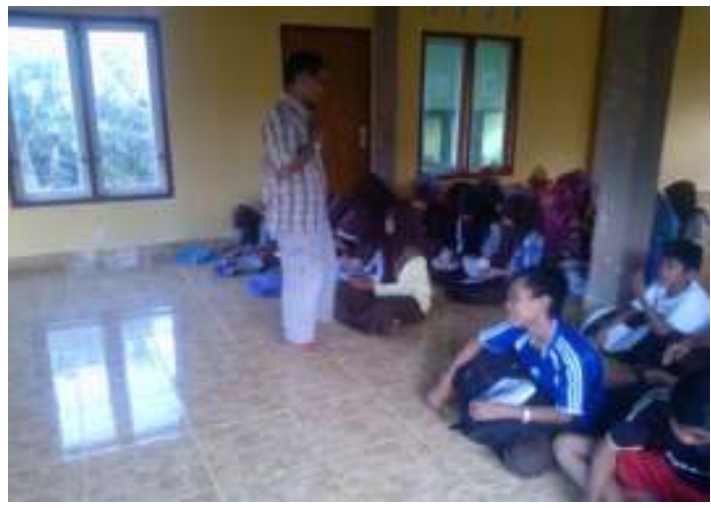

Gambar 1: Ketua Tim sedang menjelaskan materi pelatihan

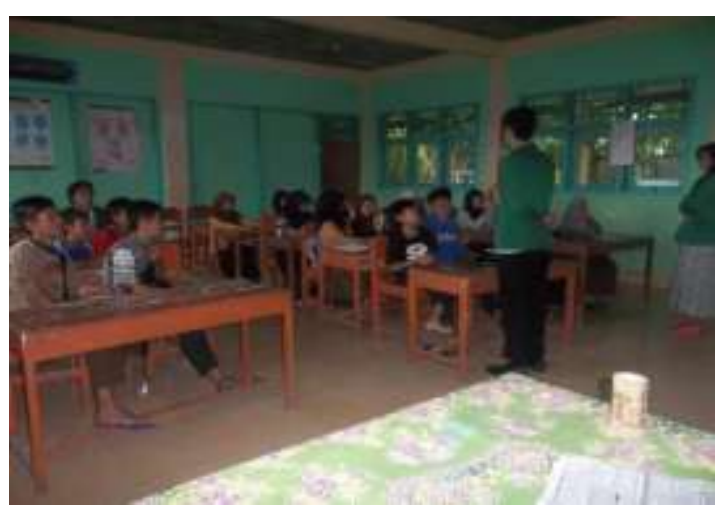

Gambar 2: Tim mahasiswa sedang menjelaskan materi pelatihan 